Geology, Geophysics \& Environment • $2012 \bullet$ Vol. 38 • No. 2 • 283-287

http://dx.doi.org/10.7494/geol.2012.38.2.283

\title{
TRASA GÓRNICZA - NOWY PODZIEMNY SZLAK W KOPALNI SOLI ,WIELICZKA"
}

\section{The Miners' Route - a new underground route in the "Wieliczka" Salt Mine}

\author{
Kopalnia Soli „Wieliczka” Trasa Turystyczna Sp. z o.o., Dziat Marketingu \\ i Public Relations; ul. Daniłowicza 10,32-020 Wieliczka; e-mail: pr@kopalnia.pl
}

Niezwykła, innowacyjna, multisensoryczna Trasa Górnicza w wielickiej kopalni umożliwia jedyną w swym rodzaju podróż w czasie i przestrzeni. Przenosi uczestników podziemnej wyprawy do minionych stuleci (aż po wiek XIV), ukazuje techniki wydobycia i pracę górnika w różnych epokach historycznych. Daje turystom możliwość podziwiania efektów wielowiekowej działalności natury w postaci geologicznych zjawisk oraz poznania tajników zawodu górniczego. W ramach Trasy Górniczej przygotowano i udostępniono do zwiedzania 21 wyrobisk komorowych i chodnikowych oraz trzy szybiki. Wyrobiska te znajdują się na trzech poziomach kopalni. Łączna długość trasy wynosi $2 \mathrm{~km}$.

Zjazd do kopalni jest zarazem przejściem do innego świata - turysta zostawia swe codzienne życie na powierzchni i na kilka godzin staje się początkującym górnikiem, czyli śleprem. Wyposażony w lampę górniczą, kask oraz pochłaniacz tlenku węgla, zdobywa wiedzę i doświadczenie pod okiem górnika przodowego, by na koniec zostać uhonorowanym certyfikatem przynależności do górniczej braci. Podczas trzygodzinnej wędrówki czeka go wiele zadań, wyzwań, przygód i niespodzianek (Fig. 1).

Swoistą kapsułą czasu jest winda, która zwozi uczestników wyprawy na I poziom (57 m), w inny świat. W głąb ziemi prowadzi szyb Regis, czyli „Królewski” - najstarszy zachowany szyb wielickiej kopalni, wydrążony w XIV wieku za panowania Kazimierza Wielkiego.

Na podszybiu przodowy przydziela zadania poszczególnym uczestnikom wyprawy: pokutnicy-metaniarze, mierniczy górniczy, tragarze, mapowi, kruszacy, pomocnik końcowego. Nazwy te są nieprzypadkowe - ściśle wiążą się z wykonywanymi zadaniami oraz tematyką zagadnień poruszanych podczas wędrówki Trasą Górniczą.

Pożary... W dawnych wiekach w kopalni trwały nawet rok. W komorze Boczaniec (XVI w.) zachowały się jeszcze ich ślady. Boczaniec wsparto kasztami - drewnianymi obudowami (najstarsze pnie użyte na Boczańcu ścięto zapewne około roku 1545, największe liczą sobie nawet $70 \mathrm{~cm}$ średnicy), na których wciąż widać czarne ślady żywiołu sprzed 400 lat.

Jedną z przyczyn pożarów był metan, dlatego przed uczestnikami wyprawy, którzy otrzymali funkcję metaniarzy, stoi odpowiedzialne zadanie: pomiar metanu przy użyciu 
specjalnych urządzeń (metanomierzy). W dawnych czasach jedynym sposobem, by uchronić się przed wybuchami tego gazu, było jego wypalanie. Tę niebezpieczną czynność wykonywali tzw. pokutnicy. Wznoszono też tamy przeciwpożarowe, np. z cegieł, płyt wykutych w soli i drewnianych kantówek. Pokrywano je dodatkowo gliną - na Trasie Górniczej można zobaczyć tego rodzaju zabezpieczenia zbudowane w XVII wieku.

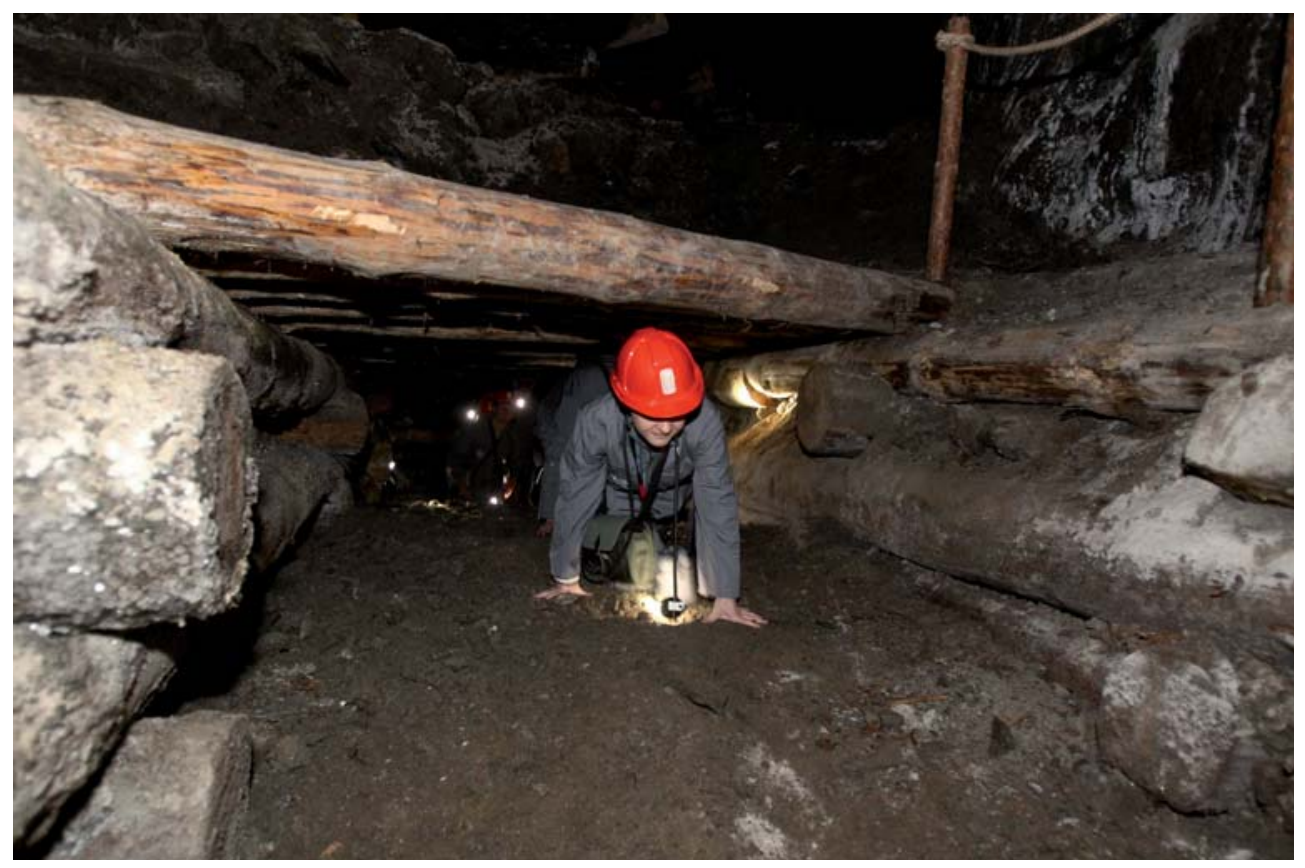

Fig. 1. Górniczy trud. Droga do komory Janik

Fig. 1. Miners' toil. The way to the Janik Chamber

Podziemia są pełne tajemnic, mocy niepojętych i nadprzyrodzonych. Zrozumiała zatem staje się górnicza religijność, o której świadczą rozsiane po kopalni miejsca kultu. Najstarsze udokumentowane miejsce sakralne znajdowało się w komorze Boczaniec - poświęcona Kunegundzie (Kindze) kapliczka stanowiła wotum za ocalenie kopalni z wielkiego pożaru z roku 1644. W roku 1697 kaplica ta spłonęła, a zarzewiem ognia okazała się - o ironio - przewrócona na ołtarz świeca. Kapliczkę jednak odbudowano, tym razem poza obrębem solnej bryły, w której wydrążono komorę Boczaniec. Z dawnego wystroju po dziś dzień zachowały się jedynie drewniane elementy ołtarza oraz zniszczone przez wilgotne powietrze figury świętych Klemensa i Stanisława ze Szczepanowa. Dostępu do wnęki z kapliczką broni solidny kaszt, wycięto w nim jednak przejście - dla pokornych, bogobojnych i zaciekawionych.

Kliny, kilofki, liny... Oprócz tego ekwipunku od XVI wieku górnicy mieli też do pomocy konie, które nie tylko obracały potężnymi kieratami na powierzchni, ale też pracowały pod zie- 
mią, ciągnąc sanice, a potem wózki z urobkiem oraz napędzając drewniane krzyże. Podziemne stajnie były przestronne i suche. Jedna z nich znajdowała się w komorze Fortymbark (XVI w.). Górnicy dbali o zwierzęta, bowiem od ich dobrej kondycji zależały postępy w pracy.

Tam gdzie są konie, jest siano. Jeśli jest siano, są też myszy. A skoro myszy, to i koty! Po dawnej kopalni buszowały zatem koty i kociska - podobno Skarbnik lubił przyjmować postać tego sprytnego i cichego zwierzęcia. Skarbnik wiedział, co robi. Zwinność przydaje się bowiem w kopalni - do komory Janik (XV w.) trzeba się niemal wczołgać (jest też łatwiejsza droga), by sprawdzić jej stan techniczny. Pomiar objętości kasztu to zadanie dla mierniczych. Nie ma miejsca na zgadywanie, trzeba brać się do pracy, z czego skrupulatnie rozliczy przodowy.

Poprzecznia Powroźnik, dawniej miejsce skręcania sznurów, lin i powrozów, dziś plener do nauki splatania liny. To ważne zadanie, w którym bierze udział cała grupa. Życie górników zależało wszak od wytrzymałości lin - te najgrubsze służyły do zjazdu i wyjazdu na powierzchnię. Lina już gotowa? Znakomicie, bo na śmiałków czekają kolejne wyzwania. Trzeba sprawdzić, czy można wejść do komory Gospoda. Górotwór przypomina żywy organizm - w jego wnętrzu wciąż oddziałują potężne siły, które trzeba monitorować. Zabezpieczanie kopalni jest procesem ciągłym. W wyeksploatowanej na przełomie XV i XVI w. komorze Gospoda zastosowano różnego rodzaju zabezpieczenia: obudowę organową, kaszt wypełniony drewnem oraz urobkiem, mur z kostek solnych przekładanych drewnem oraz filar solny.

W komorze Lipowiec (XVIII w.) znajdowała się kiedyś kaplica św. Jana (obecnie na III poziomie w obrębie trasy turystycznej). Przodowy nakazuje zgasić lampy. Kandydatów na górników ogarnia kopalniana ciemność - nieprzenikniona, pozbawiona jakichkolwiek punktów orientacyjnych. W takim mroku trudno nie przywoływać pomocy Boga i świętych patronów, trudno nie wierzyć w Skarbnika i Białą Panią. Dawny górnik musiał zawierzyć światłu kaganka. Zawsze przed szychtą pobierał garść łoju, która miała mu wystarczyć na czas pracy i powrót na powierzchnię.

Komora Korytno - pierwsza informacja o tym miejscu pochodzi z roku 1518, choć eksploatacja trwała zapewne już od wieku XV. Na miejscu kandydaci na górników odnajdują mapę. Przed mapowymi ambitne zadanie - za jej pomocą sami będą teraz wytyczać dalsze etapy wędrówki. Po drodze jeszcze pomiar konwergencji, albowiem bezpieczeństwo w kopalni jest sprawą najważniejszą.

Jeśli mapowi dobrze wykonują swe zadania, grupa trafi do komory Tanecznica (XVI w.), gdzie czekają zadania m.in. dla kruszaków. Duże zagrożenie w kopali stanowiła woda (w chodniku widoczne ujęcie wycieku wodnego) - w Tanecznicy adepci górniczego zawodu mają za zadanie uruchomić koło czerpakowe i sprawdzić za pomocą solomierzy poziom zasolenia. Odkuwanie solnej bryły przez kruszaków czy transport wózka wypełnionego urobkiem to ciężka górnicza profesja. Ślepry próbują też swoich sił z tzw. psem węgierskim.

W pochodzącej z XVII w. komorze Rzepki znajdował się kierat, który obsługiwał szybik Nadachów.

Czas na chwilę zasłużonego odpoczynku. Przodowy chętnie opowie o górniczych tradycjach. Górnicy? Cóż, to ludzie ciężkiej pracy, ale niepozbawieni poczucia humoru. Choćby taki zwyczaj karczmy, czyli odświętnego spotkania przy dobrym trunku i żartach. Jak głęboki 
jest Nadachów? Adepci górnictwa szacują jego głębokość, wrzucając kawałki soli. Szybik sięga IV poziomu kopalni.

Tymczasem grupa śleprów zmierza na poziom II. Poprzecznia Karolina, komora Franciszka Karola (XIX w.), podłużnia Klemens (XVIII w.) - już same nazwy zdradzają epokę. Czasy austriackie. Komora Franciszka Karola (Fig. 2) była jedną z atrakcji dawnej trasy turystycznej. Poświęcono ją habsburskiemu arcyksięciu, który wielicką kopalnię odwiedził dwukrotnie - wydarzenia te upamiętniono niezwykłym solnym obeliskiem. Zachowano też beczkę, którą Franciszek Karol osobiście nabił solą. Austriacy wprowadzili księgi zwiedzających - po dziś dzień znakomici goście podpisują się na ich kartach, dołączając m.in. do Fryderyka Chopina, Dymitra Mendelejewa, cesarza Franciszka Józefa I czy Jana Matejki.

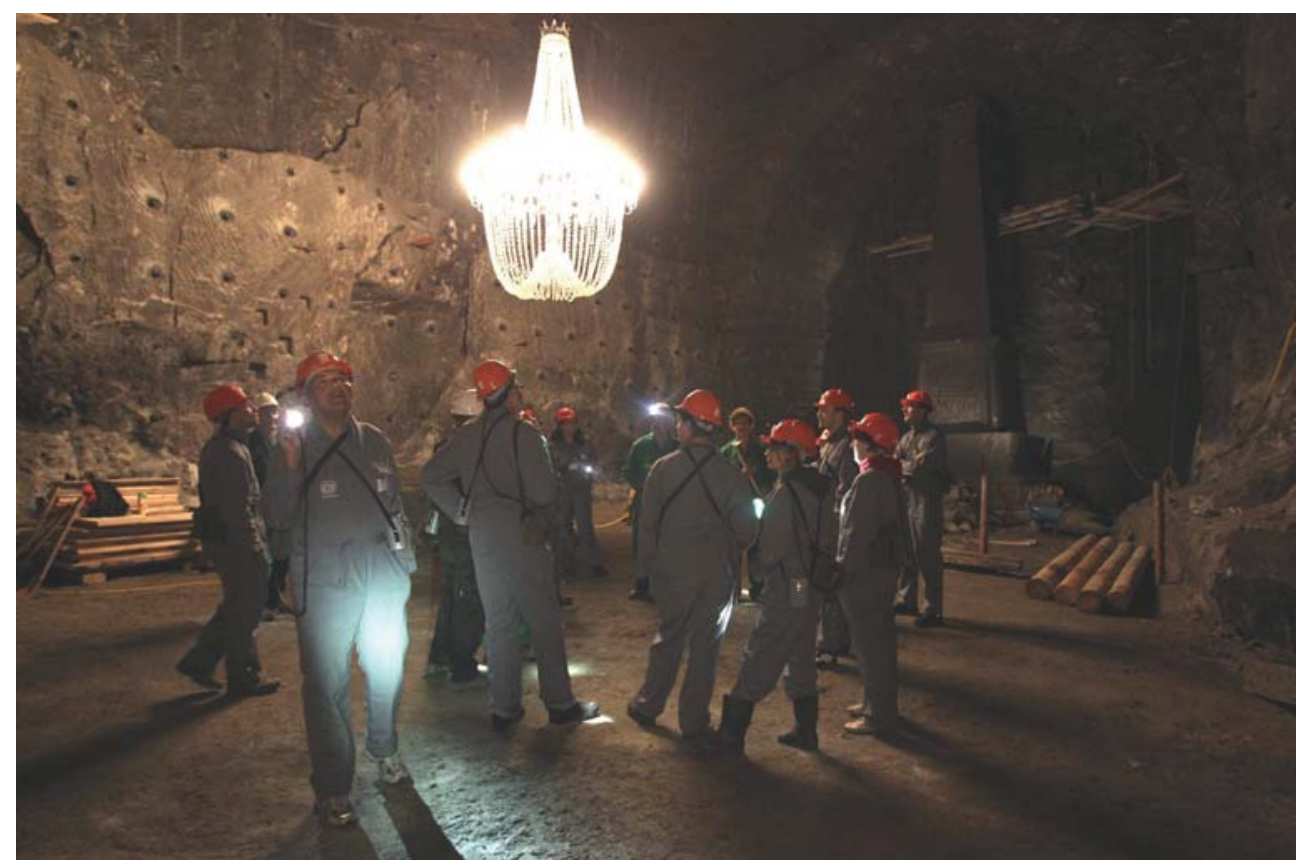

Fig. 2. Komora Franciszka Karola. W głębi solny obelisk

Fig. 2. Franciszek Karol Chamber. A saline obelisk in the background

Zwiedzanie Trasy Górniczej jest nie tylko wędrówką przez miejsca - komory i chodniki, ale również wyprawą przez stulecia. Dwie nowoczesne windy zamontowane w szybie Regis (o udźwigu 1600 kg każda, przystosowane do przewozu 21 osób) działają niczym wehikuł czasu i zabierając turystów na poziom I, jednocześnie przenoszą ich w czasy średniowiecza i renesansu, kiedy to powstał ten właśnie rejon kopalni. Im głębiej, tym bliżej współczesności. Podróż przez czas i przestrzeń kończy tradycyjny skok przez skórę - obrzęd 
ten symbolizuje przyjęcie do górniczego stanu i uczestniczą w nim wszyscy adepci wymagającego podziemnego fachu.

Prace związane z projektem Szlaki nowej przygody w zabytkowej Kopalni Soli ,Wielicz$k a$ " trwały ponad dwa lata, został on dofinansowany ze środków Europejskiego Funduszu Rozwoju Regionalnego w ramach Programu Operacyjnego Innowacyjna Gospodarka. Dotacja została przyznana w ramach Działania 6.4 Inwestycje $w$ produkty turystyczne o znaczeniu ponadregionalnym. Całkowity koszt realizacji projektu wyniósł 54101 278,03 złotych. Wartość kosztów kwalifikowanych projektu zamknęła się w 38155 889,17 złotych, z czego 21668 729,46 złotych stanowiła dotacja unijna. Na powierzchni odrestaurowano zabytkowy budynek nadszybia szybu Regis, przywrócono mu nie tylko reprezentacyjny wygląd, ale także oddano do dyspozycji turystów. Zamontowana w nim winda debiutuje w górniczych warunkach. Właściwie tego rodzaju urządzenie nie potrzebuje wieży szybowej, niemniej postawiono i tę, by Regis mógł na powrót cieszyć oczy pełnym blaskiem i podkreślać górniczy charakter Wieliczki. 